УДК 342.951:351.74

DOI https://doi.org/10.32837/apdp.v0i83.132

О. М. Правоторова

\title{
МЕТОДИ АДМІНІСТРАТИВНОЇ ДІЯЛЬНОСТІ ПУБЛІЧНОЇ АДМІНІСТРАЦІЇ В МЕХАНІЗМІ АДМІНІСТРАТИВНО-ПРАВОВОЇ ОХОРОНИ
}

Постановка проблеми. Значну роль у функціонуванні будь-якої сфери відіграють методи адміністративної діяльності публічної адміністрації як інструментарій адміністративного права. Не є виключенням із цього і проблема адміністративно-правової охорони, оскільки без методів адміністративної діяльності публічної адміністрації в механізмі адміністративно-правової охорони неможливо реально забезпечити охорону порушених прав, свобод та законних інтересів фізичних i юридичних осіб.

Мета статті. У статті на основі чинного законодавства та думок на цю проблематику вчених в галузі адміністративного права буде досліджено методи адміністративної діяльності публічної адміністрації в механізмі адміністративно-правової охорони.

Аналіз останніх досліджень і публікацій. Багато вчених із різних галузей права розглядали у своїх працях ті чи інші аспекти правової охорони взагалі, а також адміністративно-правової охорони зокрема. Також, їх цікавили питання, які автор окреслила у цій науковій статті. Але вони, як правило, зазначали про необхідність реформування правової бази, створення нових засобів щодо адміністративно-правової охорони саме своєї суспільної цінності (право власності - В. Галунько, право інтелектуальної власності - Є. Юркова, право на підприємницьку діяльність С. Сідак, атмосферне повітря - С. Ворушило, тваринний світ - В. Книш, громадський порядок - М. Лошицький, В. Цикалевич, право на комп'ютерні програми Р. Саунін, цей перелік можна ще досить довго продовжувати). Проте дієва теорія адміністративно-правової охорони, її новітня модель, сучасне концептуальне бачення до цього часу так і не отримали свого наукового втілення.

Виклад основного матеріалу дослідження. Відповідно до тлумачного словника «метод» (від гр. methodos - «шлях, спосіб дослідження, навчання викладу») - це сукупність прийомів і операцій пізнання і практичної діяльності; спосіб досягнення певних результатів у пізнанні і практиці. Застосування того чи іншого методу визначається метою пізнавальної або практичної діяльності, предметом вивчення або дії та умовами, в яких здійснюється діяльність. Кожна сфера людської діяльності має свої специфічні методи: можна говорити про методи художньої творчості; методи оброблення інформації; методи ведення війни. Так, філософія розглядає переважно методи пізнання [1].

На слушну думку С. Кічмаренка, така правова категорія, як метод, у контексті адміністративного права насамперед потрібна для визначення, яким саме чином відбувається певне правове явище чи здійснюється певний процес [2].

Методи впливу на поведінку людей - це способи функціонального налаштування окремих процесів (динаміка) та системи (статика) управління. Методи впли- 
ву, що обумовлюють належну поведінку колективів та окремих людей у процесі управління, різняться стимулами, що спонукають до певних дій [3].

Метод публічного права - імперативний метод правового регулювання - $є$ іманентним методом і права адміністративного, визначаючи специфіку впливу його норм на суспільні відносини, особливість юридичних режимів, що створюється даною галуззю права. Імперативний метод у публічному праві (як і диспозитивний у приватному) - первинний, тобто властивий усім галузям публічного права[4, с. 276].

Метод адміністративного права - це прийоми та способи цілеспрямованого впливу на поведінку учасників адміністративно-правових відносин [3].

На погляд М. Шульги, Ю. Битяка, під методом зазвичай розуміють спосіб або засіб досягнення поставленої мети. Відповідно до цього адміністративно-правовими методами є способи та прийоми безпосереднього й цілеспрямованого впливу виконавчих органів (посадових осіб) на підставі закріпленої за ними компетенції, у встановлених межах і відповідній формі на підпорядковані їм органи та громадян $[5$, c. $158 ; 6$, с. 56$]$.

Методи виявляються у формах управління, через взаємодію суб'єктів і об’єктів управління, зв'язки, що між ними склалися. У них відбиваються воля держави, повноваження юридично-владного характеру, що належать виконавчим органам. Тому методи управління юридично оформлені, закріплені адміністративно-правовими нормами [5, с. 158].

Слід звернути увагу на визначення методу державного управління, яке з позиції більшості дослідників - це способи, прийоми, шляхи досягнення цілей, вирішення завдань та здійснення його функцій і повноважень [7, с. 61]. Зокрема, за думкою В. Авер'янова, воно трактується як певні способи практичного здійснення органами виконавчої влади та іншими суб'єктами державного управління владно-організаційного впливу на керовані об'єкти, що відповідають характеру й обсягу наданих цим суб'єктам функцій і повноважень (компетенції), а також особливостям керованих об'єктів [8, с. 72].

В. Галунько та В. Курило визначають, що методи діяльності публічної адміністрації - це способи, прийоми цілеспрямованого впливу норм адміністративного права на поведінку учасників адміністративно-правових відносин із метою публічного забезпечення прав і свобод людини та громадянина, нормального функціонування громадянського суспільства й держави [9, с. 151]. В. Коваленко під цією категорією розуміє спосіб, прийом практичної реалізації її суб'єктами завдань і функцій у повсякденній діяльності на основі закріпленої за ними компетенції, у встановлених межах і відповідній формі [10, с.483]. Професор Ю. Битяк вважає, що це науково обгрунтовані, дозволені законом способи впливу на керовані об'єкти з метою найбільш правильного оперативного вирішення управлінських завдань i досягнення максимальної ефективності управління [11, с. 157; 2].

Таким чином, в юридичній літературі домінує схожа думка щодо цієї проблематики. Під методом адміністративної діяльності (державного управління, публічного управління адміністрування) провідні вчені-адміністративісти визначають способи, прийоми цілеспрямованого впливу норм адміністративного права на поведінку учасників адміністративно-правових відносин з метою досягнення кінцевих 
завдань адміністративно-правової охорони. Іншими словами, у більшості випадків це кінцевий правовий інструмент адміністративно-правової охорони, після якого має бути забезпечене відновлення порушеного права - досягнута ефективність адміністративно-правової охорони.

Класично до методів діяльності публічної адміністрації відносять переконання і примус [12, с. 162-175]. Як зазначає Т. Коломоєць, адміністративний примус - це визначені нормами адміністративного права способи офіційного фізичного або психологічного впливу уповноважених державних органів, а у деяких випадках - і громадських організацій - на фізичних та юридичних осіб у вигляді особистих, майнових, організаційних обмежень їх прав, свобод та інтересів у випадку вчинення цими особами протиправних діянь або в умовах надзвичайних обставин, з метою попередження та припинення протиправних діянь або в умовах надзвичайних обставин, з метою попередження та припинення протиправних діянь, забезпечення провадження в справах про правопорушення, притягнення винних осіб до відповідальності, попередження та локалізації наслідків надзвичайних ситуацій [13, с. 16$]$.

Щодо юридичної природи та класифікації заходів адміністративного примусу О. Джафарова вважає, що адміністративно-запобіжні заходи застосовуються з метою попередження правопорушень і надзвичайних обставин, локалізації їх наслідків, забезпечення громадського порядку в разі їх виникнення. Заходи адміністративного припинення застосовуються з метою припинення об'єктивної сторони правопорушення та недопущення настання більш шкідливих наслідків, відновлення попереднього правомірного стану.

Заходи адміністративної відповідальності застосовуються з метою покарання винних у вчиненні адміністративного проступку. Щодо виділення саме такої групи, то виділення адміністративних стягнень є занадто вузьким, адже застосування інших адміністративних покарань повністю відповідає ознакам адміністративного примусу, а виділення групи відповідальності за порушення адміністративно-правових положень навпаки - не має меж. До заходів адміністративної відповідальності, на думку вченої, слід віднести: адміністративні стягнення, що застосовуються до фізичних осіб (ст. 24 КУпАП); заходи впливу, що застосовуються до неповнолітніх (ст. 24-1 КУпАП); стягнення, передбачені адміністративним законодавством, щодо юридичних осіб; заходи адміністративного впливу, що застосовуються до юридичних осіб, і не визнані законодавцем стягненнями [14].

Залежно від мети застосування адміністративно-запобіжних заходів, які застосовуються публічною адміністрацією, вони поділяються на дві групи: 1) заходи, які застосовуються для попередження чи виявлення конкретних правопорушень або правопорушень з боку конкретних осіб; 2) заходи, які застосовуються для забезпечення громадського порядку і громадської безпеки за різних надзвичайних обставин. Залежно від характеру правоохоронного впливу адміністративно-запобіжні заходи класифікуються на такі види: особистісні, організаційні та майнові; залежно від форми їх процесуального вираження - письмові й такі, що виявляються в певних матеріально-технічних діях; виходячи зі строків реалізації-ті, що реалізуються шляхом виконання [9, с. 146-150] 
Адміністративно-запобіжні заходи, які застосовуються публічною адміністрацією при здійсненні адміністративно-правової охорони, є найчисленнішим видом таких заходів. Завдяки ним створюються умови для виявлення правопорушень i подальшого їх припинення, а також установлення особи правопорушника і притягнення його до відповідальності (перевірка документів, огляд) чи попереджається вчинення правопорушень конкретними особами (взяття на облік, адміністративний нагляд за особами, звільненими з місць позбавлення волі [9, с. 146-150].

У свою чергу заходи адміністративного припинення мають за мету своєчасне реагування на ті чи інші антигромадські діяння, припинення, переривання протиправної поведінки і тим самим - недопущення настання їі шкідливих наслідків. Вони спрямовані на примусове переривання (припинення) діянь, які мають ознаки адміністративного правопорушення, а в окремих випадках - і кримінально-правовий характер, недопущення шкідливих наслідків протиправної поведінки, забезпечення провадження у справі про адміністративне правопорушення і притягнення винних до адміністративної, а у виняткових випадках - до кримінальної відповідальності.

Залежно від різних критеріїв заходи адміністративного припинення в діяльності публічної адміністрації поділяються: залежно від мети застосування - на самостійні (оперативні) та допоміжні (забезпечувальні); за характером правоохоронного впливу - на особистісні, організаційні та майнові; за формою процесуального вираження - на усні, письмові та виражені в певних матеріально-технічних діях; за характером застосування - на заходи загального і спеціального призначення. Фактичними підставами застосування правоохоронними органами заходів адміністративного припинення є конкретна протиправна ситуація, яку в майбутньому може бути визнано адміністративним проступком, злочином або об'єктивно протиправним діянням душевнохворого чи малолітнього. Також до таких заходів належить забезпечення провадження у справах про адміністративні проступки в діяльності правоохоронних органів [15].

Третім складником адміністративного примусу є адміністративні санкції, як невід’ємна складова адміністративної відповідальності. Адміністративна відповідальність - це різновид юридичної відповідальності, специфічна форма негативного реагування з боку держави в особі уповноважених органів на відповідну категорію протиправних діянь (передусім адміністративних проступків), а особи, які скоїли зазначені правопорушення, повинні відповісти перед уповноваженим державним органом за свої неправомірні дії і понести адміністративне стягнення в установлених законом формах і порядку. Адміністративній відповідальності, як різновиду юридичної відповідальності, притаманні такі ознаки: 1) має зовнішній характер; 2) застосовується лише за вчинення правопорушення; 3) пов'язана з державним примусом у формах каральних і правовідновлювальних заходів; 4) визначена у нормах права; 5) притягнення правопорушника до відповідальності здійснюється в певному процесуальному порядку; 6) притягнення до відповідальності здійснюється уповноваженими державними органами та посадовими особами; 7) винна у вчиненні правопорушення особа несе певні втрати матеріального та побутового характеру, які передбачені законом. 
Як показує викладена вище теорія адміністративного права щодо юридичної природи адміністративної відповідальності, невід’ємним її складником є державний примус. Цей примус визначається в санкціях норм адміністративного права. На жаль, прикладів накладення цієї санкції дуже багато. Кожного року більше трьох мільйонів фізичних осіб притягується до адміністративної відповідальності і до них застосовуються адміністративні санкції. Крім того вагомий адміністративно-охоронний вплив мають санкції, які накладаються на юридичних осіб. Усі вони, як ті, що накладаються на фізичних осіб, а також ті, що накладаються на юридичних осіб, є такими, що прямо забезпечують адміністративну-правову охорону.

Висновки. Адміністративно-правова охорона - це інститут адміністративного права, що складається з однорідних норм адміністративного права, правовий вплив яких спрямовано на попередження правопорушень (профілактику злочинів) та відновлення порушених прав, свобод та законних інтересів фізичних і юридичних осіб, що здійснюються за допомогою адміністративного інструментарію - форм адміністративної діяльності публічної адміністрації, засобів адміністративного примусу та адміністративних процедур.

Отже, до особливостей концептуальних засад методів адміністративної діяльності публічної адміністрації у сфері адміністративно-правової охорони відноситься те, що до них не належать методи заохочення і переконання, оскільки вони не використовуються при відновленні та попередженні протиправних посягань на права, свободи й законні інтереси фізичних і юридичних осіб, а публічна адміністрація може використовувати весь арсенал адміністративно-запобіжних, адміністративно-попереджувальних заходів та адміністративного примусу, а також метод адміністративного контролю для досягнення загальних і спеціальних цілей адміністративно-правової охорони.

\section{Jimepamypa}

1. Яременко В., Сліпушко О. Новий словник української мови в 3-х т. Київ : Аконіт. 2008. 928 с.

2. Кічмаренко С. Адміністративно-правове забезпечення незалежності судової влади в Україні. Дисертація на здобуття наукового ступеня кандидат юридичних наук. Інститут публічного права. Київ. 2017. URL:http://sipl.com.ua/?page_id=4302.

3. Кісіль 3., Кісіль Р. Адміністративне право : навчальний посібник. Київ : ЦУЛ, 2011. 696 с.

4. Римаренко Ю., Мойсеєв Є., Олефір В. та інші. Адміністративна (поліцейська) діяльність органів внутрішніх справ (Загальна частина) : підручник. Київ : $K H T, 2008.816$ с.

5. Битяк Ю., Гаращук В., Шульга М. та інші. Адміністративне право України : підручник. Київ : Юрінком Інтер, 2006. $544 \mathrm{c}$.

6. Чернявский А.Г., Габричидзе Б.Н. Административное право : учебник. 2-е издание. Издательство : ВЕЛБИ, 2006. 680 с.

7. Струс-Духнич Т. Роль і місце судової влади у правовій державі. Наукові записки Львівського університету бізнесу та права. 2011. Вип. 6. С. 171-175.

8. Авер'янов В. Адміністративне право України. Академічний курс : підруч. Том 2. Особлива частина ред. Київ : Юрид. думка, 2005. 624 с.

9. Галунько В.В., Курило В.І., Короєд С.О. та інші. Адміністративне право України. Т. 1. Загальне адміністративне право : навчальний посібник. Херсон : Грінь Д.С., 2015. 272 с.

10. Коваленко В. Курс адміністративного права України : підручник. Національна академія внутрішніх справ. Київ : Юрінком Інтер, 2012.808 с.

11. Битяк Ю. Адміністративне право України. Підручник. Київ : Юрінком Інтер. 2005.

12. Васильєв А.С. Адміністративне право України. Харків : «Одісей», 2002. 288 с. 
13. Коломоєць Т.О. Адміністративний примус у публічному праві України: теорія, досвід та практика реалізації : автореф. дис. ... д-ра юрид. наук: 12.00.07, Харк. нац. ун-т внутр. справ. Харків, $2005.43 \mathrm{c}$.

14. Джафарова О. Іванцов В. Проблеми класифікації заходів адміністративного примусу. Aктуальні проблеми державного управління. 2007. № 1 (31). С. 59-67.

15. Рудницький С. Категорія «механізм» у суспільних науках : SOCIAL-SCIENCE. 2011. URL: http://social-science.com.ua/article/630.

\section{Анотація}

Правоторова О. М. Методи адміністративної діяльності публічної адміністрації в механізмі адміністративно-правової охорони. - Стаття.

Метою статті є дослідження методів адміністративної діяльності публічної адміністрації в механізмі адміністративно-правової охорони. Визначені ознаки адміністративної відповідальності, як різновиду юридичної відповідальності: має зовнішній характер; застосовується лише за вчинення правопорушення; пов'язана з державним примусом у формах каральних і правовідновлювальних заходів; визначена у нормах права; притягнення правопорушника до відповідальності здійснюється в певному процесуальному порядку; притягнення до відповідальності здійснюється уповноваженими державними органами та посадовими особами; винна у вчиненні правопорушення особа несе певні втрати матеріального та побутового характеру, які передбачені законом.

3'ясовано, що заходи адміністративного припинення мають за мету своєчасне реагування на ті чи інші антигромадські діяння, припинення, переривання протиправної поведінки і тим самим - недопущення настання її шкідливих наслідків.

Адміністративно-правова охорона - це інститут адміністративного права, що складається з однорідних норм адміністративного права, правовий вплив яких спрямовано на попередження правопорушень (профілактику злочинів) та відновлення порушених прав, свобод та законних інтересів фізичних і юридичних осіб, що здійснюються за допомогою адміністративного інструментарію - форм адміністративної діяльності публічної адміністрації, засобів адміністративного примусу та адміністративних процедур.

До особливостей концептуальних засад методів адміністративної діяльності публічної адміністрації у сфері адміністративно-правової охорони відноситься те, що до них не належать методи заохочення і переконання, оскільки вони не використовуються при відновленні та попередженні протиправних посягань на права, свободи й законні інтереси фізичних і юридичних осіб, а публічна адміністрація може використовувати весь арсенал адміністративно-запобіжних, адміністративно-попереджувальних заходів та адміністративного примусу, а також метод адміністративного контролю для досягнення загальних і спеціальних цілей адміністративно-правової охорони.

Ключові слова: відповідальність, адміністративно-правова охорона, загроза, законодавство, національна безпека, суспільні відносини, адміністративно-правовий захист, публічна адміністрація, адміністративно-правові відносини.

\section{Summary}

Pravotorova $O$. M. Methods of administrative activity of public administration in the mechanism of administrative legal protection. - Article.

The purpose of the article is to study the methods of administrative activity of public administration in the mechanism of administrative and legal protection. The signs of administrative responsibility are defined as a kind of legal responsibility: it is external; applies only to the commission of an offense; State coercion in the form of punitive and remedial measures; defined in the rules of law; prosecution of the offender is carried out in a certain procedural order; prosecution is carried out by authorized state bodies and officials; the person guilty of the offense carries some material and domestic losses, which are stipulated by law. It has been established that the measures of administrative termination are aimed at timely response to certain anti-social actions, termination, interruption of unlawful behavior and thereby preventing its harmful consequences.

It is concluded that administrative-legal protection exists through a system of administrative-legal norms, and at the same time it is proved that it can not, from the point of view of epistemology of law, exist in such narrow limits as the state determines, it reflects objective social relations, protects the most important values, Which during this period of time may not yet find the formal registration in the sources of administrative law, is provided on the basis of administrative law and simultaneously governed by the norms of administrative law, which will establish not only the state, although it primarily.

The peculiarities of the conceptual principles of methods of administrative activity of public administration in the field of administrative and legal protection include the fact that they do not belong to the 
methods of encouragement and persuasion, since they are not used in the restoration and prevention of unlawful encroachments on the rights, freedoms and legitimate interests of individuals and legal entities, and public administration can use the whole arsenal of administrative, preventive, administrative and coercive measures, as well as ministratyvnoho controls to achieve the general and specific objectives of administrative and legal protection.

Key words: responsibility, administrative and legal protection, threat, legislation, national security, public relations, administrative and legal protection, public administration, administrative-legal relations, administration. 